\title{
The effect of logistics management, supply chain facilities and competitive storage costs on the use of warehouse financing of agricultural products
}

\author{
Paramita Prananingtyas $^{\mathrm{a}^{*}}$ and Siti Zulaekhah ${ }^{\mathrm{b}, \mathrm{c}}$
}

${ }^{a}$ Diponegoro University, Indonesia

${ }^{b}$ Lecturer, Pekalongan University, Indonesia

${ }^{c}$ LPDP Awardee, PhD Student of The Doctoral Program at Faculty of Law, Diponegoro University

\section{H R O N I C L E}

\begin{tabular}{l}
\hline Article history: \\
Received October 28,2020 \\
Received in revised format \\
January, 15, 2021 \\
Accepted January 172021 \\
Available online \\
January 182021 \\
\hline Keywords: \\
Logistics Management \\
Supply Chain Facilities \\
Competitive Storage Costs \\
Warehouse Financing \\
Supply Chain Management
\end{tabular}

\section{A B S T R A C T}

This study seeks to analyze the effect of logistics management carried out by warehouse operators, the facilities and access provided to support storage, and the competitiveness of storage costs on the use of warehouse financing by suppliers in Central Java, Indonesia. The sampling method was purposive random sampling. The numbers of respondents involved in this study were 120 suppliers and farmers producing first-rate agricultural products and who are users of warehouse receipts in the Central Java region. By using linear regression analysis with assistance, the study results found that the variables of logistic management, facilities and supply chain access as well as competitive storage costs have positive and significant effects on the use of warehousing financing by suppliers and farmers who use public warehousing. This result confirms that the more precisely warehousing is managed, the higher the level of trust of users involved in the logistics business and supply chain of agricultural products to use additional services in the form of warehouse receipts to support the sustainability of agricultural businesses.

\section{Introduction}

Stakeholders and the Indonesian government continue to strive to encourage increased competitiveness of national trade and economic growth in Indonesia by optimizing the role of logistics industry facilities in the country. Optimization of competitiveness and fulfillment of demand for agricultural products in the country is carried out by streamlining supply chains between regions. Rexhausen et al. (2012) stated that distribution is the most important element in the relationship activity between customers and the company's internal supply chain. Here, the supply chain is important to be carried out effectively and efficiently considering the risk of scarcity of raw materials for the continuity of domestic industry and trade. According to Edi et al., (2019), the supply chain for food commodities requires a mechanism of integration and connectivity between stakeholders in order to obtain optimal benefits for each stakeholder. The food supply chain, especially agricultural products in Indonesia, experiences complexity due to the interconnection network of suppliers / farmers, collectors, wholesalers, exporters and industry (Berland et al., 2014). According to Edi (2019), stakeholders involved in the warehouse receipt system to support the supply chain are managers, supervisors and registration bodies, which play an important role in the warehouse receipt system that provides storage services for goods and integrates the supply chain of agricultural products from upstream to downstream. In terms of regulations, to support an effective supply chain and support food security while ensuring the sustainability and welfare of suppliers and farmers, the government through Law Number 9 of 2011 concerning the Warehouse Receipt System developed an idea to secure warehouse receipt securities as Asset Backed Securities. The importance of supporting warehouse financing such as this receipt was also reinforced by Wu et al., (2010) who argue that disruption to the assurance and trust of stakeholders involved in the supply chain can result in the supply

* Corresponding author

E-mail address: pptyas@live.undip.ac.id (P. Paraningtyas)

C 2021 by the authors; licensee Growing Science.

doi: $10.5267 /$ j.uscm.2021.1.004 
chain losing production capacity, which is positively more likely to have a significant impact on the performance of the entire supply chain network.

Asset-backed financing guarantees in the supply chain, such as warehouse receipts, have long been regarded as one of the supporters of sustainability in supply chain management. Dolgui \& Proth (2010) stated the strategic role of warehouses in supply chain management. Nian (2012) states that one of the distinctive innovations of modern logistics is warehouse financing that accommodates financial services in the supply chain, and provides solutions to financing problems for grassroots level stakeholders and small and medium enterprises. Likewise, Miranda et al., (2019) specifically researched warehouse receipts, and found that warehouse receipt financing can enable smallholders, especially in developing countries to store their surpluses safely in modern warehouses for sale at a later date when temporary higher prices allow them to use the commodity stored as collateral to obtain loans to temporarily finance household consumption and investment needs. In this context, Wu \& Dong (2007) also emphasize the importance of analyzing warehouse performance in a logistic network to improve performance and in line with the development of the warehousing industry complex, which does not only concern supply chain aspects but also financing. In the specific context of warehouse receipts as a guarantee of financing for suppliers, farmers and small and medium enterprises, several studies have investigated the important role of warehouse receipts in the food supply chain (Miranda et al., 2018; Su \& Wang, 2020; Mulangu et al., 2017; Heinemann, 2017; Coulter \& Onumah, 2002; Höllinger et al., 2009). This study seeks to analyze the effect of logistics management carried out by warehouse operators, the facilities and access provided to support storage, and the competitiveness of storage costs on the use of warehouse financing by suppliers and farmers in Central Java, Indonesia.

\section{Literature Review and Hypothesis}

\subsection{Supply Chain Management Based on Asset Backed Securities}

Management, availability and warehousing network is one of the most crucial parts of supply chain management worldwide. Various studies have documented the important role of warehousing as the backbone of supply chain management. In this context, most of the literature starts from the role of warehouses from the side of large producers who are usually worldclass manufacturers that provide finished goods to consumers (Tanwari, 2020), but studies on the function and management of warehousing for raw products from first-level suppliers such as farmers and small and medium enterprises with many of their agricultural products being missed (Ganeshan, 1999; Ramaa et al., 2012; Jaruphongsa et al., 2004; Singh et al., 2018; Biswal et al., 2018). In this context, the support and management of warehouse administrators to provide trust and financial guarantees such as warehouse receipts for first-rate users is considered critical in relation to the space utilization in public warehousing to ensure the welfare of farmers and guarantee the stock of agricultural products. In its function to guarantee warehouse utility as well as asset-based guarantee for small scale suppliers and farmers, Miranda et al., (2019) define warehouse receipts as documents issued by warehouse managers as evidence that a certain commodity with a stated quantity and quality has been stored in a particular warehouse by a tested store. Kumar (2014) states that Asset Backed Securities (ABS) are created through a securitization process in which loans are packaged and sold as securities, a type of loan that is usually guaranteed. When a consumer takes a loan, the amount owed becomes an asset on the lender's balance sheet. Lenders sell these assets to trusts or special purpose vehicles, which package them into asset-backed securities that can be sold in the market. ABS issuers benefit from new sources of funding as a result of ABS issuance while ABS buyers benefit from higher yields from ABS and facilitate portfolio diversification. This type of securitization is supported by a wider range of guarantees including credit card bills, vehicle payables, SME securitization, leasing, and other collectible financial assets (other receivables).

\subsection{Effect of Logistics Management on Warehouse Financing}

In analyzing the relationship between logistics management and warehouse performance, Cormier and Gunn (1992) proposed several criteria such as production capacity, storage and warehouse design related to warehouse performance. In the context of warehouse management retrieval capacity, policies are essential to define storage assignments, and to maximize optimal space utilization with warehouse size. Furthermore, in the context of logistics management, Ziggers \& Henseler (2016) found that supply base orientation can play an important role as a strategic asset and has a contribution to contribute to superior performance, in addition to the company's customer orientation aspects. This shows the importance of the interaction between the distributions of capabilities in logistics management with the strategic orientation possessed by warehouse managers. Grosse et al., (2015) states that warehousing is a cornerstone in logistics management that requires a combination of the effectiveness and efficiency aspects of space, time and human resource management. Human resource management development in warehousing design and development can be positively linked to performance and reduce long-term costs (Grosse et al., 2015; Mughal, 2019). Faber et al. (2013) found that task complexity and market dynamics had a significant effect on planning extensiveness in warehouse management. In addition, other considerations in the context of logistic management, such as the complexity of decision rules, and sophistication of control also affect warehouse management (Faber et al., 2013). In general, this illustrates that properly managed logistics management has a higher impact on customer relationships. In the context of logistics and supply chain in the agricultural business, adequate logistics 
management will affect the confidence of suppliers and farmers producing agricultural products to use warehousing financing services. Based on this description, the hypotheses proposed in this study are:

\section{$\boldsymbol{H}_{1 .}$ There is a positive effect of logistics management on the use of warehouse financing.}

\subsection{Supply Chain Facilities and Access on the Warehouse Financing}

Davarzani and Norrman (2015) practically underline that a business environment such as e-commerce has an effect on warehousing demand and performance. Meneghetti \& Monti (2015) stated that volume control has an effect on reducing the total annual cost of storage facilities. In addition, competitiveness for warehouse costs is also related to energy use for operations and investment costs have an effect on warehousing performance. In analyzing the effects of sales practices and operations planning on manufacturing operational performance, Thomé et al., (2014) found a positive effect of internal operating standards on manufacturing performance. In management terms, this indicates the importance of controlling business size, market dynamics and economic development. In addition, it is found that supply chain integration has a moderating effect that increases the effect of operating standards on performance. Specifically, in analyzing facilities and performance, Atieh et al., (2016) stated that several facilities related to warehousing procedures have an important effect on performance such as software to handle transactions, and facility layout. This means that the availability of facilities and access in logistics and supply chains has a higher effect on customer relationships. In the context of logistics and supply chains in the agricultural business, adequate facilities and access for users will affect the confidence of supplier and farmers producing agricultural products to use warehousing financing services. Based on this description, the hypotheses proposed in this study are:

\section{$\boldsymbol{H}_{2}$ Supply chain facilities and access has a positive effect on the use of warehouse financing.}

\subsection{The effect of Competitive Processing Costs on the Warehouse Financing}

In the supply chain to measure warehouse performance, Staudt et al., (2015) use several performance indicators, namely time, cost, quality and productivity. Furthermore, De Koster \& Balk (2008) found a relationship between efficiency of warehouse space utilization and productivity. Gu et al., (2010) specifically evaluated the relationship between warehouse design and warehouse performance evaluation. Using a formal stochastic dynamic model of seasonal commodity marketing, Miranda et al., (2019) investigated the relationship between risk reallocation that undermines the benefits of warehouse receipt financing and transaction costs for smallholders. Christopher (1993) states that a sustainable competitive advantage in the logistics business can be achieved by combining a customer service strategy and lowering service costs. This can affect the creation of long-term sustainable relationships with logistics users. In particular, by investigating the role of costs with customer relationship management, Kubon \& Krasnodębski (2010) state that proper management can have an effect on reducing logistics costs and can affect competitiveness. Furthermore, in agricultural business, Wajszczuk (2005) found that larger regional agricultural enterprises tended to have high logistical costs, dominated by physical flow costs. This means that the more competitive logistics costs for storing in warehouses have a higher impact on customer relationships to use financing products to support their businesses. In the context of logistics and supply chain in the agricultural business, more competitive logistic costs for users will affect the confidence of suppliers and farmers producing agricultural products to use warehousing financing services. Based on this description, the hypotheses proposed in this study are:

\section{$\boldsymbol{H}_{3 .}$ Competitive processing costs has a positive effect on the use of warehouse financing.}

\section{Method}

This study aims to analyze the effect of logistic management carried out by warehouse administrators, facilities and access provided to support storage, and storage cost competitiveness in the use of warehouse financing by suppliers and farmers in Central Java, Indonesia. This study uses a quantitative design to empirically analyze the relationship and significance between the independent variables and the dependent variable. The independent variables in this study are logistic management (X1), facilities and access in storage logistics in the warehouse (X2) and competitive storage costs (X3), while the dependent variable is the use of warehousing financing through warehouse receipts (Y) by users in this logistics business. In this study, items as a measure of each construct were adopted from Gunawan et al., (2019). Specifically, variable of logistic management (X1) in this study is measured by human resources management, warehouse receipt processing, compliance with regulations and user knowledge. For the variable of facility and access (X2), it is measured by the adequacy of facilities, access to credit and financing at financial institutions, access to market information, and the adequacy of other information to help suppliers and farmers. The competitive storage cost variable (X3) in this study is measured by warehouse rental costs, cost of transportation, cost of processing and cost of insurance. For the variable measurement, the use of warehousing financing (Y) in this study is measured by the suppliers and farmers' perceptions of the continuity of the warehouse receipt program, expansion of market access, and expectations of higher selling prices. The sampling method was purposive random sampling. The numbers of respondents involved in this study were 120 suppliers and farmers producing first-rate agricultural products and who are users of warehouse receipts in the Central Java region. The data was 
collected by distributing questionnaires with closed questions with a 5-point Likert scale. The analysis results were obtained using linear regression analysis with the help of the SPSS program.

\section{Results}

The study results present descriptive statistics of the values of each item measured in this study. Descriptive statistics display the minimum, maximum, mean and standard deviation values for each item of the independent and dependent variables in this study (Table 1). The results show that all items get a minimum value of 3 and a maximum of 5 of the 5 points on the scale used. For the mean obtained, the results show a range of values between 3.85 (X22) to 4.31 (Y1), while for the standard deviation obtained, it ranges from 0.39 (X23) to 0.53 (X12).

Table 1

Descriptive Statistics

\begin{tabular}{ccccc}
\hline & Min & Max & Mean & Std. Dev \\
\hline Y1 & 3 & 5 & 4.3167 & 0.48 \\
Y2 & 3 & 5 & 4.1167 & 0.39 \\
Y3 & 3 & 5 & 4.1167 & 0.41 \\
X11 & 3 & 5 & 4.1083 & 0.40 \\
X12 & 3 & 5 & 4.1333 & 0.53 \\
X13 & 3 & 5 & 3.9667 & 0.52 \\
X14 & 3 & 5 & 4.1333 & 0.48 \\
X21 & 3 & 5 & 3.9667 & 0.44 \\
X22 & 3 & 5 & 3.8500 & 0.51 \\
X23 & 3 & 5 & 4.1167 & 0.39 \\
X24 & 3 & 5 & 4.0167 & 0.52 \\
X31 & 3 & 5 & 3.9500 & 0.48 \\
X32 & 3 & 5 & 4.0500 & 0.48 \\
X33 & 3 & 5 & 3.9250 & 0.52 \\
X34 & 3 & 5 & 3.8833 & 0.51 \\
\hline
\end{tabular}

Subsequent testing shows the Pearson correlation which shows a correlational relationship between the two variables of all the variables studied. The results show that the dependent variable of use of warehouse financing has significant correlational values of $0.623,0.688,0.727$, respectively, with independent variables of logistic management, facilities and access and competitive storage costs. Furthermore, in the relationship between the independent variables, it is found that the logistic management was related to the facilities and access by 0.566 (sig. 0.000 ) and by 0.547 (sig. 0.000 ) with the competitive storage cost variable. Furthermore, the correlation value of facility and access variable with competitive storage cost variable is significant at 0.633 (sig. 0.000) (Table 2).

Table 2

Pearson Correlations

\begin{tabular}{ccccc}
\hline Variable & $\mathrm{Y}$ & $\mathrm{X} 1$ & $\mathrm{X}$ & $\mathrm{X}$ \\
\hline $\mathrm{Y}$ & - & $.623^{* *}$ & $.688^{* *}$ & $.727^{* *}$ \\
(Sig. 2-tailed) & & $(.000)$ & $(.000)$ & $(.000)$ \\
X1 & $.623^{* *}$ & & $.566^{* *}$ & $.547^{* *}$ \\
(Sig. 2-tailed) & $(.000)$ & - & $(.000)$ & $(.000)$ \\
X2 & $.688^{* *}$ & $.566^{* *}$ & - & $.633^{* *}$ \\
(Sig. 2-tailed) & $(.000)$ & $(.000)$ &. & $(.000)$ \\
X3 & $.727^{* *}$ & .547 & $.633^{* *}$ & - \\
(Sig. 2-tailed) & $(.000)$ & $(.000)$ & $(.000)$ & - \\
\hline
\end{tabular}

$* *$. Correlation is significant at the 0.01 level (2-tailed).

$\mathrm{X} 1=$ Logistic Management; X2= Facilities and Access; X3=Competitive Costs; $Y=$ Use of Warehouse Financing

The next test is hypothesis testing. The statistical results show a positive and significant effect of logistic management variable on the use of warehouse financing, which is indicated by the $\beta$ (Std) coefficient value of 0.228 with the t-stat. 3.258 and p-value of $0.001<0.05$ at the $95 \%$ confidence level. This proves empirically that the logistic management variable has a significant and positive effect on the use of warehouse financing. Thus, the first hypothesis which states the positive effect of management logistics on the use of warehouse financing is accepted (Table 3). The second hypothesis testing states that the facilities and logistic access variable has a significant effect on the use of warehousing financing as the main link in supply management. This is indicated by the coefficient value of 0.297 with a $p$-value of $0.00<0.05$. This shows that the facilities and logistical access variable has a significant effect on the use of warehousing financing, which means that the higher the quality and availability of facilities and access for logistic warehouse users, the higher the likelihood of users using financing services through warehouse receipts as a basis for space utilization in the system supply chain. So, the second hypothesis is accepted. 
Table 3

Hypothesis Testing

\begin{tabular}{|c|c|c|c|c|c|c|c|}
\hline \multicolumn{3}{|c|}{ Hypothesis } & $\beta$ (unstd.) & Std. Error & $\beta$ (Std) & $\mathbf{t}$ & Sig. \\
\hline $\begin{array}{c}\text { Logistic } \\
\text { Management }\end{array}$ & $\rightarrow$ & $\begin{array}{c}\text { Use of Warehouse } \\
\text { Financing }\end{array}$ & .166 & .051 & .228 & 3.258 & .001 \\
\hline $\begin{array}{c}\text { Facilities and } \\
\text { Access }\end{array}$ & $\rightarrow$ & $\begin{array}{c}\text { Use of Warehouse } \\
\text { Financing }\end{array}$ & .225 & .057 & .297 & 3.926 & .000 \\
\hline Competitive Costs & $\rightarrow$ & $\begin{array}{c}\text { Use of Warehouse } \\
\text { Financing }\end{array}$ & .289 & .052 & .415 & 5.565 & .000 \\
\hline \multicolumn{3}{|c|}{ Constant } & 1.679 & .762 & & 2.202 & .030 \\
\hline
\end{tabular}

Statistical testing also shows that there is a positive effect of competitive storage price variable on the use of warehousing financing, which is indicated by the coefficient value of 0.415 with a p-value of $0.000<0.05$. This shows that there is a significant effect of competitive price variables on the use of warehousing financing, which means that the more competitive the price offered, the higher the likelihood of using warehouse receipt services by first-rate suppliers of agricultural products. This means that the third hypothesis which evaluates the effect of competitive price variables on the use of warehousing financing is accepted.

Table 4

Analysis of Variance

\begin{tabular}{lccccc}
\hline & Sum of Squares & df & Mean Square & F & Sig. \\
\hline Regression & 59.416 & 3 & 19.805 & 71.163 & $.000^{\mathrm{a}}$ \\
Residual & 32.284 & 116 & .278 & & \\
\hline Total & 91.700 & 119 & & & \\
\hline Predictors: (Constant), Logistic Management; Facilities and Access; Competitive Costs; Dependent Variable: Warehouse
\end{tabular}

Further analysis evaluates the simultaneous influence of the independent variable of logistic management, facilities and access and competitive storage costs on the use of warehousing financing. The results of the analysis show that all the independent variables simultaneously have an influence on the dependent variable, which is proven empirically with an Fvalue of 71,163 with a significance level of $0.000<0.05$ at the $95 \%$ confidence level (Table 4). The next analysis is to confirm the influence of the independent variables on the dependent variable by using the coefficient of determination through the adjusted R-square. The analysis result shows the adjusted R-square value of 0.639 or 63.9 percent of the total effect. This means that about two-thirds of the predicted dependent variability for warehousing financing can be measured by the three independent variables used in this study in the form of logistic management, facilities and access and competitive storage costs (Table 5).

Table 5

The Coefficient of Determination of Logistic Management, Facilities and Access and Competitive Costs on the Use of Warehouse Financing

\begin{tabular}{lcccc}
\multicolumn{1}{c}{ Model } & R & R Square & Adjusted R Square & $\begin{array}{c}\text { Std. Error of the } \\
\text { Estimate }\end{array}$ \\
\hline $\begin{array}{l}\text { Predictors: (Constant), Logistic Management; } \\
\text { Facilities and Access; Competitive Costs }\end{array}$ & $.805^{\text {a }}$ & .648 & .639 & .52755 \\
\hline
\end{tabular}

\section{Discussion}

The findings show that there are possibilities, opportunities and challenges in developing warehouse receipts as an investment instrument to increase the sustainability of the warehouse receipt system as the foundation of the supply chain. In this case, warehouse receipts with collateral status give birth to a bank or other financial institution as the originator. This institution has a central role in the asset securitization process. This finding supports Grosse et al., (2015) which underlines the importance of the strategic orientation possessed by warehouse managers. Warehousing is the cornerstone of logistics and supply chain management not only for large manufacturing industries, but also for first-level suppliers who provide raw materials to the market or industry. Logistics and supply chain management in the context of warehousing requires a combination of the effectiveness and efficiency aspects of space, time, and human resource management. These findings also support Faber et al., (2013) who emphasized task complexity and market dynamics in logistics warehouse management. The findings also support several previous studies that emphasize the importance of providing facilities and access as well as competitive pricing. In the context of facilities and performance, Atieh et al., (2016) stated that several facilities related to warehousing procedures have an important effect on performance, such as software to handle transactions, and facility layout. Furthermore, in the context of costs, Krasnodębski (2010) states that proper management can have an effect on reducing logistics costs and can have an effect on competitiveness. In general, this study also confirms Gunawan et al., 
(2019) who presented the findings that the sustainability of the warehouse receipt system requires a combination of management competitiveness by warehouse administrators and supplier-farmers' needs to obtain evidence that can be used as collateral for their savings in agricultural products. These results also confirm Miranda et al., (2019) who confirm that warehouse receipts are possible to function as collateral for loans with the support of the right legal and regulatory framework. Here, warehouse receipts can function as a formal financial instrument, allowing depositors to provide collateral for stored commodities to other parties without requiring physical delivery. These findings also confirm Aday \& Aday (2020) who encourage financial support for small suppliers and farmers or vulnerable people who are involved in the supply chain from food production, processing, distribution and demand.

\section{Conclusion}

The findings have shown that all independent variables in the form of logistic management, facilities and supply chain access as well as competitive storage costs have a positive and significant effect on the use of warehousing financing by smallholders who use public warehousing. This confirms that the more precisely warehousing is managed, the higher the level of trust of users involved in the logistics and supply chain business of agricultural products to use additional services in the form of warehouse receipts to support the sustainability of their business. In addition, these findings also empirically confirm that improving facilities and market access for logistics and supply chain business users can increase the use of financial services offered by the warehousing business as the cornerstone of supply chain management. Finally, the logistics business in the field of warehousing is managerially emphasized to increase the competitiveness of logistics costs to increase wider access for small scale suppliers and farmers to use services and get benefits from warehouse receipt services. The research results practically suggest the need for legal platform support in the securitization process in warehouse receipts as one of the cornerstones of supply chain management in Indonesia to open opportunities for collection rights for warehouse receipt credit for securitization. The voluntary originator position allows the development of warehouse receipts as an assetbacked effect to make business decisions that support expansion of warehouse receipt-based supply chains. In addition, suggestions are also aimed at other commodities such as cocoa, rattan, coffee, pepper that have international competitiveness to be developed effectively through supply chain management supported by warehouse receipts as asset-backed securities.

\section{References}

Aday, S., \& Aday, M. S. (2020). Impacts of COVID-19 on food supply chain. Food Quality and Safety, fyaa024.

Atieh, A. M., Kaylani, H., Al-abdallat, Y., Qaderi, A., Ghoul, L., Jaradat, L., \& Hdairis, I. (2016). Performance improvement of inventory management system processes by an automated warehouse management system. Procedia Cirp, 41, 568572.

Berland, N. J., Klakegg, O. J., \& Sefland, A. M. (2014). Stakeholder Management Fieldbook: Get started with Stakeholder Management. Nils Jacob Berland.

Biswal, A. K., Jenamani, M., \& Kumar, S. K. (2018). Warehouse efficiency improvement using RFID in a humanitarian supply chain: Implications for Indian food security system. Transportation Research Part E: Logistics and Transportation Review, 109, 205-224.

Christopher, M. (1993). Logistics and competitive strategy. European Management Journal, 11(2), 258-261.

Cormier, G., \& Gunn, E. A. (1992). A review of warehouse models. European journal of operational research, 58(1), 313.

Davarzani, H., \& Norrman, A. (2015). Toward a relevant agenda for warehousing research: literature review and practitioners' input. Logistics Research, 8(1), 1.

De Koster, M. B. M., \& Balk, B. M. (2008). Benchmarking and monitoring international warehouse operations in Europe. Production and Operations Management, 17(2), 175-183.

Dolgui, A., \& Proth, J. M. (2010). Supply chain engineering: useful methods and techniques. Springer Science \& Business Media.

Edi, S., Siregar, H., Baga, L. M., \& Suroso, A. I. (2019). Analisis pemangku kepentingan rantai pasok rumput laut indonesia berbasis sistem resi gudang. Buletin Ilmiah Litbang Perdagangan, 13(2), 281-308.

Faber, N., De Koster, M. B. M., \& Smidts, A. (2013). Organizing warehouse management. International Journal of Operations \& Production Management, 33(9), 1230-1256

Ganeshan, R. (1999). Managing supply chain inventories: A multiple retailer, one warehouse, multiple supplier model. International Journal of Production Economics, 59(1-3), 341-354.

Grosse, E. H., Glock, C. H., Jaber, M. Y., \& Neumann, W. P. (2015). Incorporating human factors in order picking planning models: framework and research opportunities. International Journal of Production Research, 53(3), 695-717.

Gu, J., Goetschalckx, M., \& McGinnis, L. F. (2010). Research on warehouse design and performance evaluation: A comprehensive review. European Journal of Operational Research, 203(3), 539-549.

Gunawan, E., Kuwornu, J. K., Datta, A., \& Nguyen, L. T. (2019). Farmers’ Perceptions of the Warehouse Receipt System in Indonesia. Sustainability, 11(6), 1690.

Heinemann, F. (2017). The case for Co-financing the CAP (No. 04). EconPol Working Paper.

Höllinger, F., Rutten, L., \& Kiriakov, K. (2009, June). The use of warehouse receipt finance in agriculture in ECA countries. In Technical background paper for the World Grain Forum (pp. 6-7). 
Jaruphongsa, W., Cetinkaya, S., \& Lee, C. Y. (2004). Warehouse space capacity and delivery time window considerations in dynamic lot-sizing for a simple supply chain. International Journal of Production Economics, 92(2), 169-180.

Kubon, M., \& Krasnodębski, A. (2010). Logistic costs in competitive strategies of enterprises. Agricultural Economics, 56(8), 397-402.

Kumar, R. (2014). Strategies of banks and other financial institutions: Theories and cases. Elsevier.

Meneghetti, A., \& Monti, L. (2015). Greening the food supply chain: an optimisation model for sustainable design of refrigerated automated warehouses. International Journal of Production Research, 53(21), 6567-6587.

Miranda, M. J., Mulangu, F. M., \& Kemeze, F. H. (2019). Warehouse receipt financing for smallholders in developing countries: Challenges and limitations. Agricultural Economics, 50(5), 629-641.

Miranda, M., Mulangu, F., Kemeze, F. H., \& Kolavalli, S. (2018). Does warehouse receipt financing benefit Ghanaian smallholders? (Vol. 13). Intl Food Policy Res Inst.

Mughal, M. (2019). Impact of Green Supply Chain Management Practices on Performance of Manufacturing Companies in Jordan: A Moderating Role of Supply Chain Traceability. Arthatama, 3(2), 67-82.

Mulangu, F. M., Kemeze, F. H., \& Miranda, M. J. (2017). Warehouse Receipts and Financial Practices: The Case of Ghana. Technical Report, African Center for Economic Transformation, Accra, Ghana.

Nian, L. I. U. (2012). Risk Assessment Research about Financing Warehouse of Enterprise. Journal of Hunan Industry Polytechnic, 6.

Ramaa, A., Subramanya, K. N., \& Rangaswamy, T. M. (2012). Impact of warehouse management system in a supply chain. International Journal of Computer Applications, 54(1).

Rexhausen, D., Pibernik, R., \& Kaiser, G. (2012). Customer-facing supply chain practices-The impact of demand and distribution management on supply chain success. Journal of Operations Management, 30(4), 269-281.

Singh, R. K., Chaudhary, N., \& Saxena, N. (2018). Selection of warehouse location for a global supply chain: A case study. IIMB Management Review, 30(4), 343-356.

Staudt, F. H., Alpan, G., Di Mascolo, M., \& Rodriguez, C. M. T. (2015). Warehouse performance measurement: a literature review. International Journal of Production Research, 53(18), 5524-5544.

Su, L., \& Wang, H. (2020, April). Analysis on Electronic Warehouse Receipt of Bulk Commodity in Supply Chain Finance Practice. In 2020 International Conference on Computer Information and Big Data Applications (CIBDA) (pp. 33-36). IEEE.

Tanwari, A. (2020). A Study on Assessing the Relationship between Green Marketing and Brand Loyalty in Manufacturing Sector of Greece: A Moderating Role 0f Green Supply Chain Practices. Arthatama, 4(1), 44-55.

Thomé, A. M. T., Sousa, R. S., \& Scavarda do Carmo, L. F. R. R. (2014). The impact of sales and operations planning practices on manufacturing operational performance. International Journal of Production Research, 52(7), 2108-2121.

Wajszczuk, K. (2005). Logistics costs analysis as an assisting tool to achieve competitive advantage for agricultural enterprises (No. 724-2016-49026).

Wu, Y., \& Dong, M. (2008). Combining multi-class queueing networks and inventory models for performance analysis of multi-product manufacturing logistics chains. The International Journal of Advanced Manufacturing Technology, 37(56), 564-575.

Wu, Y., Dong, M., Tang, W., \& Chen, F. F. (2010). Performance analysis of serial supply chain networks considering system disruptions. Production Planning and Control, 21(8), 774-793.

Zhao, L., \& Huchzermeier, A. (2018). Supply chain finance. In Supply Chain Finance (pp. 105-119). Springer, Cham.

Ziggers, G. W., \& Henseler, J. (2016). The reinforcing effect of a firm's customer orientation and supply-base orientation on performance. Industrial Marketing Management, 52, 18-26. 
(C) 2021 by the authors; licensee Growing Science, Canada. This is an open access article distributed under the terms and conditions of the Creative Commons Attribution (CC-BY) license (http://creativecommons.org/licenses/by/4.0/). 